\title{
David Faure, Emperor and ancestor: State and lineage in South China
}

John Lagerwey

\section{OpenEdition}

1 Journals

Édition électronique

URL : http://journals.openedition.org/chinaperspectives/2353

DOI : 10.4000/chinaperspectives.2353

ISSN : 1996-4617

Éditeur

Centre d'étude français sur la Chine contemporaine

Édition imprimée

Date de publication : 15 septembre 2007

ISSN : 2070-3449

Référence électronique

John Lagerwey, «David Faure, Emperor and ancestor: State and lineage in South China », China

Perspectives [En ligne], 2007/3 | 2007, mis en ligne le 09 avril 2008, consulté le 21 septembre 2020.

URL : http://journals.openedition.org/chinaperspectives/2353 ; DOI : https://doi.org/10.4000/

chinaperspectives. 2353

Ce document a été généré automatiquement le 21 septembre 2020.

(C) All rights reserved 


\title{
David Faure, Emperor and ancestor: State and lineage in South China
}

\author{
John Lagerwey
}

1 For thirty years, David Faure has been deconstructing our image of an "eternal" and timeless China. According to this image, China was a society dominated by Confucian scholars from powerful families: the "gentry". Their core values were expressed in the form of family ideology and ancestor worship and seemed inscribed since time immemorial, especially in South China, in the very structure of the villages where the vast majority of the population still lived. Hence, the most beautiful building in these southern villages, the one built at the very centre of the village, would invariably be the ancestor shrine.

2 This image of China served as the basis of the organisation of our knowledge and judgement: if corruption and nepotism characterised Imperial and then Republican China, including its trade relations with the West, if China despised merchants and had no laws to protect trade and private property, if China was incapable of modernising itself, and, more recently, if China had no "civil society", it was because it was Confucian, and because Confucius, already, had prized relationship values-such as filial piety and loyalty-more highly than abstract laws applicable to all.

In his first book, The Structure of Chinese Rural Society : Lineage and Village in the Eastern New Territories, Hong Kong (Hong Kong and Oxford, Oxford University Press, 1986), Faure had demonstrated that there was another China, not of lineage but of territory, not of ancestors but of the gods honoured in Taoist worship. In this new book, which has been twenty years in the making (p. xi), he describes how the China in which our distorted image originates emerged during the Ming Dynasty (1368-1644) and then prevailed under the Qing (1644-1911), before being eradicated in the revolutions of the 20th century. It is the most ambitious attempt ever written to rethink the history of modern China and, thus to restore China to its rightful place in a world history struggling to invent itself. Any attentive reader of this book will no longer take part in the sometimes inquisitorial and always arrogant debates about what China "lacked" in 
order to invent capitalism, democracy, science, civil society and human rights, in short: "modernity".

4 The book's thread, to summarize it in a few lines, begins before the Ming (Chapters 2 to 5), when the State and its Confucian ideology had hardly penetrated the region of the Pearl River Delta, of which this book recounts the history. Nonetheless, a distinction had already emerged between "us"-the administered population and its administrators - and "them", the Dan (people of the water), the Yao (people of the mountain), and later, the Hakka. At the heart of this society were local temples, and above all, Buddhist monasteries, with enormous estates and special relationships with the government. It was under the Ming (chapters 6 to 12) that the modern lineage developed. The registering of the population at the beginning of this dynasty was the first step in this development. In the mid-15th century, with the monetarisation of the economy and the establishment of a single tax calculated in silver, the population registers that served as the base of taxation and forced labour, were transformed into land registers whose only purpose was raising taxes. This was to completely transform the relationship between the State and society since the State, henceforth, was more interested in the land register than in the population. Since, in the meantime, lineages had appeared, there was no other entity more suitable for ensuring the registering of lands and the collection of taxes.

Indeed, under the influence of the neo-Confucian ideology of $\mathrm{Zhu} \mathrm{Xi,} \mathrm{which} \mathrm{from} \mathrm{the}$ beginning of the dynasty became State orthodoxy, the right to sacrifice to one's ancestors, which up till then had been exclusively reserved to aristocrats and higher officials, had begun to spread, until in the 1530s, it was extended to commoners, who even acquired the right to sacrifice to the "founding ancestors". The collective practice of sacrificing to a distant ancestor, usually the real or imaginary founder of a village or a group of villages, encouraged a sense of linear belonging which transcended space and time, and was thus one of the necessary conditions for the emergence of the vast and wealthy lineages of South China under the Ming and the Qing. At the same time, the fact that the State did not require that lands be registered by their individual owners but allowed them to be registered collectively, made it possible for lineages to register their lands under the names of their ancestors, and thus to make the lineage a real corporation. (Thus was born the "family business", so typical of China before 1949.)

6 It was therefore the blending of ideological and practical concerns, at the level of both State and scholars, which led the lineages to transform villages by placing in their centre a shrine dedicated to their ancestors and pushing to the edges, or even eradicating completely, the now "indigenous" divinities (p. 193). The Confucian "standardisation" of southern Chinese society was accompanied by campaigns against the Yao, and the destruction of popular temples, including Buddhist monasteries (there were two major local campaigns, in 1489 and 1521). In 1537, Huo Tao, a man from the Delta who was Minister of Rites at the time, even organised attacks against monasteries in Beijing. Faure concludes that "The new society which emerged during the 16th century began to look like the society led by the gentry which students of 19th century China long took to be a 'tradition' which was never called into question in China" ( $p$. 148).

7 Since the essence of Faure's thesis aims at explaining how neo-Confucian lineage came, under the Ming Dynasty, to embody local society and thus to become the privileged interlocutor of the State, the present review will not dwell on the Qing epoch (Chapters 
13 to 22). These chapters are, however, as rich in detail as the previous ones on the evolution of local society in its transactions with the State. In these chapters we witness the "proliferation of lineage institutions" (Chapter 14), the development in the religious domain of a growing gap between the scholars and the people (Chapter 15), the "incorporation" of lineage by means of its rituals as well as by the ownership of land (Chapter 16) and then, after chapters on business prosperity in the 18th century and the militarisation of society in the 19th century, the attribution of China's weakness and backwardness in comparison with Western invaders to the same institution of the lineage which, according to Liang Qichao, writing after his return from the United States in 1904, explains why the Chinese "are qualified to be people of the lineage, but not citizens" and even less of being individuals (pp. 344-45).

In his epilogue (Chapter 23), after referring to the evidence which tends to prove that Chinese society evolved in other regions in the same way as in the Pearl River Delta, David Faure concludes with a heartfelt call for an end to history written without any resort to field work: "One has to travel to be impressed by China's vastness and its varied character. One has to travel also to see at first hand the relics that stand as testimony of the society of a bygone age. And one has to travel even to gather the documentary information that still abides on stone steles or fragments of paper tenderly preserved in private hands. Time is running out for this approach to the writing of Chinese history" (p. 368). 